\title{
MAPPING THE HAZARDS OF TRANSPORT OF DANGEROUS SUBSTANCES BY RAIL
}

\author{
Iva ŽITNÍKOVÁ ${ }^{1}$, Pavlína PUŽOVÁ ${ }^{2}$, Aleš BERNATÍK ${ }^{3}$
}

Review article

Abstract: $\quad$ The aim of the following contribution is the mapping of hazards of transport of dangerous
substances on a chosen railway stretch in the Moravian-Silesian Region. The mapping will
be used for the preparation of a new module "Railway" for the prototype software system
FLOREON ${ }^{+}$. The mapping focuses on railway critical points, such as level crossings,
underpasses, bridges, where an increased risk of accidents exists. The contribution also
deals with the issue of the most common causes of more or less severe railway accidents
leading to injury and/or loss of human life and property damage.
Mapping, Hazard, Dangerous substances, Risk, Rail transport.

\section{Introduction}

At present, the significance of rail transport generally grows because the issue of substitution of rail transport for tank truck transport on highways (roads, motorways) has been increasingly debated recently. From the general point of view, almost all the modes of transport can be characterised by a growing accident rate at which human health is endangered or harmed and a loss of human life and material damage and, last but not least, endangerment or pollution of the environment may occur.

In the framework of cooperation between the Faculty of Safety Engineering (FSE) and the Faculty of Electrical Engineering and Computer Science (FEECS) of VŠB - Technical University of Ostrava, preparation of an extension to the system FLOREON $^{+}$by a new module - "Railway" was agreed. FLOREON ${ }^{+}$is a prototype software system being prepared by FEECS. This system is designed for the modelling and simulation of situations caused by unfavourable natural events with using advanced calculation and internet technologies. For the preparation of the module "Railway", mobile sources of threat (of the rail transport of dangerous substances) will be mapped in the area of the Moravian-Silesian Region. This module is intended above all for the services of the Integrated Rescue System (mainly the Fire and Rescue System of the Moravian-Silesian Region).

This contribution deals with the creation of a basic overview of sources of threat on a chosen railway stretch in the Moravian-Silesian Region for the module "Railway" being prepared.

\section{Materials and methods}

\section{Transport of Dangerous Substances by Rail}

In our country, dangerous substances are transported and substances designated in compliance with valid legal regulations as dangerous substances are handled very often. From this, an increased threat of release of them into individual components of the environment, especially soil, water and atmosphere, during railway accidents, operating troubles and standard manipulation results.

In the area of transport, a general term "dangerous goods" is used. Dangerous goods include both substances and articles the transport of which is, according to the regulations concerning the international carriage of dangerous goods by rail - RID, excluded or allowed only under conditions determined in the regulations. RID is the part of the Intergovernmental Convention for International Carriage by Rail - COTIF, which brings together more than 40 contracting parties, as Member States, to constitute the Intergovernmental Organisation for International Carriage by Rail - OTIF. The Czech Republic signed this protocol, which complies with the legislation of the European Union, at the meeting at Lithuanian Vilnius in the year 1999 (Ministerstvo dopravy ČR, 2011).

The fundamental law for the area of rail transport in the Czech Republic is the Act No. 266/1994 Coll., on railways, as subsequently amended. Within the meaning of this Act, the release of dangerous substances, which will occur during railway operation or rail transport and which will endanger the environment, is an extraordinary event.

VŠB - Technical University of Ostrava, Faculty of Safety Engineering, Ostrava, Czech Republic, iva.zitnikova.st@vsb.cz VŠB - Technical University of Ostrava, Faculty of Safety Engineering, Ostrava, Czech Republic, pavlina.puzova.st@vsb.cz VŠB - Technical University of Ostrava, Faculty of Safety Engineering, Ostrava, Czech Republic, ales.bernatik@vsb.cz 
Within the meaning of the Act No. 17/1992 Coll., on the environment, as subsequently amended, and the Act No. 254/2001 Coll., on water, as subsequently amended, releases of dangerous substances into the environment are qualified as accidental releases, the consequence of which is the exceeding of the allowable carrying capacity of the land - in other words it is a case of environmental accident.

The significance of individual modes of transport is evident every year not only in the number of columns of cars on roads and generally in the extent of utilization of traffic channels, but also in statistical data. The extent of utilization of individual modes of transport in past years can be seen in Tab. 1 .

Tab. 1 Comparison of transport performance of goods transport (Ročenka dopravy, 2010)

\begin{tabular}{|l|c|c|c|c|c|c|}
\hline & $\mathbf{2 0 0 0}$ & $\mathbf{2 0 0 5}$ & $\mathbf{2 0 0 6}$ & $\mathbf{2 0 0 7}$ & $\mathbf{2 0 0 8}$ & $\mathbf{2 0 0 9}$ \\
\hline $\begin{array}{l}\text { Goods transport } \\
\text { in total }\left(10^{3} \mathrm{t}\right)\end{array}$ & 523249 & 560037 & 554994 & 565708 & 540731 & 458328 \\
\hline Rail transport & 98255 & 85613 & 97491 & 99777 & 95073 & 76715 \\
\hline Road transport & 414725 & 461144 & 444574 & 453537 & 431855 & 370115 \\
\hline $\begin{array}{l}\text { Inland water } \\
\text { transport }\end{array}$ & 1907 & 1956 & 2032 & 2242 & 1905 & 1647 \\
\hline Air transport & 16 & 20 & 22 & 22 & 20 & 14 \\
\hline Oil pipelines & 8346 & 11305 & 10875 & 10131 & 11877 & 9837 \\
\hline
\end{tabular}

Rail transport is the second after road transport in the extent of utilization. This is not the only reason why it is necessary to pay an increased attention to rail transport and to deal with its safety.

\section{Risk Mapping}

Risk mapping is used for the representation of risks in a map. It is a process during which territories with different levels of risk are identified and results of risk assessment are represented in special maps (so-called risk maps). A risk map makes it possible to identify risk composition and level for each part of the territory. A risk is considered here comprehensively a summary of risks for individual types of extraordinary events.

When mapping the risks, we use results of analyses of manifestations of possible extraordinary events in the territory as a basis; the results can be processed on the basis of numerical model calculations (e.g. release of dangerous substances, break wave in case of dam failure), long-term meteorological and hydrological statistical observations, observation of natural events, etc.

The results of risk mapping can be represented in maps, e.g. by colour visualization - colour-coded scale of risk level. A boundary between individual risk levels can be sometimes disputable, because it depends on the approach of a person determining the boundary. (Krömer et al., 2010).

$$
R_{i}=\left(e_{i}, n_{i}, p_{i}, t\right)
$$

Risk is the combination pi of the probability of a certain event ei and its averse consequences $n_{i}$ (Oravec, 2009). The probability represents credibility or degree of various phenomena in a given period of time. (JANOTA et al., 2008). The consequences is expressed quantitatively or qualitatively as the result of an event which may be, for example loss of human life or property.

Risk is a tool for quantifying the causal dependence. Solution prevention in the causal dependence is shown in the following Fig. 1.

Hazard hides object property, which may under certain circumstances cause events with potentially adverse consequences. It represents the conditions for the threat of unwanted phenomenon. Threat means the hazard of exposure, a condition where hazard can be activated (JANOTA et al., 2008). The threat is natural or man-conditional process that poses a potential threat to human society. Vulnerability is a complex property that reflects weaknesses in the system, its reduced resistance to the possible disruption of its function, damage or destruction. Vulnerability expresses the degree of damage in the event of a dangerous phenomenon. (ŠIMÁK et al., 2006).

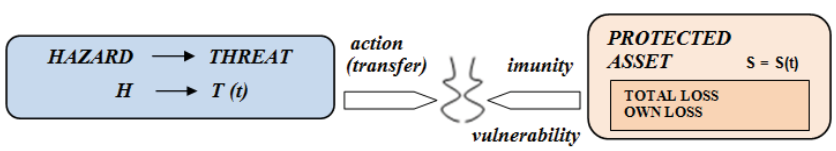

Fig. 1 The solution to prevent the causal dependence (according ROUDNÝ, 2008)

We can take advantage of the proposed categories according to the severity of the Ministry of Defense of the United States of America to evaluate the consequences of the interpretation of adverse events, which is intended for environmental management and health and safety at work (see Tab. 2). 
Tab. 2 Suggested mishap severity categories (MIL STD 882D)

\begin{tabular}{|c|c|c|}
\hline Category & Description & $\begin{array}{l}\text { Environmental, Safety, and } \\
\text { Health Result Criteria }\end{array}$ \\
\hline I & 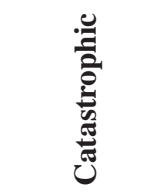 & $\begin{array}{l}\text { Could result in death, permanent } \\
\text { total disability, loss exceeding } \\
\$ 1 \mathrm{M} \text {, or irreversible severe } \\
\text { environmental damage that } \\
\text { violates law or regulation. }\end{array}$ \\
\hline II & : & $\begin{array}{l}\text { Could result in permanent } \\
\text { partial disability, injuries or } \\
\text { occupation illness that may result } \\
\text { in hospitalization of at least three } \\
\text { personnel, loss exceeding } \$ 200 \mathrm{~K} \\
\text { but less than } \$ 1 \mathrm{M} \text {, or reversible } \\
\text { environmental damage causing } \\
\text { a violation of law or regulation } \\
\text { where restoration activities can be } \\
\text { accomplished. }\end{array}$ \\
\hline III & $\begin{array}{l}\text { 预 } \\
\text { 莺 } \\
\sum\end{array}$ & $\begin{array}{l}\text { Could result in injury or } \\
\text { occupation illness resulting in } \\
\text { one or more lost work days }(\mathrm{s}) \text {, } \\
\text { loss exceeding } \$ 10 \mathrm{~K} \text { but less } \\
\text { than } \$ 200 \mathrm{~K} \text {, or mitigatible } \\
\text { environmental damage without } \\
\text { violation of law or regulation } \\
\text { where restoration activities can be } \\
\text { accomplished. }\end{array}$ \\
\hline IV & 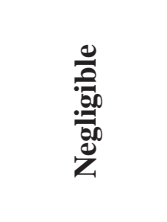 & $\begin{array}{l}\text { Could result in injury or illness } \\
\text { not resulting in a lost work day, } \\
\text { loss exceeding } \$ 2 \mathrm{~K} \text { but less than } \\
\$ 10 \mathrm{~K} \text {, or minimal environmental } \\
\text { damage not violating law or } \\
\text { regulation. }\end{array}$ \\
\hline
\end{tabular}

\section{Hazard Mapping}

The importance of mapping of hazards (danger/critical points) consists especially in the determination of total load of a territorial unit or its part. Subsequently, it consists in the determination of parameters for adequate preparedness of the given territory/part of territory for coping with extraordinary events of both natural and anthropogenic character. The objective of risk mapping is the identification of areas vulnerable to certain risks. Information provided by risk mapping represents a significant tool for planning bodies of local and state governments.

The mapping of hazards (sources of risks) is the fundamental step for risk mapping. The basis is formed by maps of individual types of threats.

For the needs of risk mapping, it is suitable to divide the types of hazards into two basic categories:

a) without a specific risk source - to this category, we classify area hazards without a territorially defined source. Nevertheless, a range of consequences of an extraordinary event can be expressed e.g. statistically (windy areas, snowy areas); in other words, the vulnerability of the territory to extraordinary event occurrence can also be expressed statistically. Examples of the hazards are stated in Tab. 3.

b)with a specific risk source - to this category, we include such hazards for which we can determine specific risk sources (e.g. watercourse, hydraulic structure, chemical plant, etc.) and a related defined territory for which the consequences of an extraordinary event can be expressed using GISs (floodplain, break wave, etc.). Examples of these hazards are stated in Tab. 4 and 5. (Krömer et al., 2010).

Tab. 3 Types of hazards of natural character - without a specific risk source (according to Krömer et al., 2010)

\begin{tabular}{|l|l|}
\hline \multicolumn{1}{|c|}{ Threat } & \multicolumn{1}{c|}{ Possible consequences } \\
\hline $\begin{array}{l}\text { Long-term heat } \\
\text { and drought }\end{array}$ & $\begin{array}{l}\text { Fire. } \\
\text { Track distortion. }\end{array}$ \\
\hline $\begin{array}{l}\text { Long-term inverse } \\
\text { situation }\end{array}$ & Interruption of transport. \\
\hline Vast forest fires & $\begin{array}{l}\text { Damage of electrical power, } \\
\text { gas and centralized heat supply } \\
\text { systems - lines, tractions. } \\
\text { Interruption of transport. } \\
\text { Decrease in transport } \\
\text { performance. }\end{array}$ \\
\hline $\begin{array}{l}\text { Heavy snowfall, } \\
\text { snow storm, glaze } \\
\text { and back ice }\end{array}$ & $\begin{array}{l}\text { Damage of overhead power lines } \\
\text { and switching systems. } \\
\text { Covering the track with snow. } \\
\text { Fall of a foreign body onto the } \\
\text { track (tree, line, pole, etc.). }\end{array}$ \\
\hline $\begin{array}{l}\text { Storm, strong gale, } \\
\text { hurricane }\end{array}$ & $\begin{array}{l}\text { Damage of overhead power lines } \\
\text { and switching systems. } \\
\text { Fall of a foreign body onto the } \\
\text { track (tree, line, pole, etc.). }\end{array}$ \\
\hline Lightning & $\begin{array}{l}\text { Damage of overhead power } \\
\text { systems and switching systems. }\end{array}$ \\
\hline
\end{tabular}

Tab. 4 Types of hazards of natural character - with a specific risk source (according to Krömer et al., 2010)

\begin{tabular}{|c|c|c|}
\hline Source & Hazard & Possible consequences \\
\hline $\begin{array}{l}\text { Hydraulic } \\
\text { structure, } \\
\text { river, } \\
\text { stream }\end{array}$ & $\begin{array}{l}\text { Floods, } \\
\text { flooding, } \\
\text { storm } \\
\text { rainfall }\end{array}$ & $\begin{array}{l}\text { Flooding, subsurface } \\
\text { erosion, subgrade } \\
\text { transport, damage to the } \\
\text { track. } \\
\text { Interruption of transport. } \\
\text { Decrease in transport } \\
\text { performance. }\end{array}$ \\
\hline
\end{tabular}


Tab. 5 Types of hazards on the track - with a specific risk source (according to Krömer et al., 2010)

\begin{tabular}{|c|c|c|}
\hline Source & Hazard & Possible consequences \\
\hline $\begin{array}{l}\text { Track failure, } \\
\text { railwayman's error }\end{array}$ & Derailing of a rail vehicle & $\begin{array}{l}\text { Damage to life and health of persons. } \\
\text { Loss of property. } \\
\text { Leakage of dangerous liquids and } \\
\text { environmental damage. } \\
\text { Interruption of transport. }\end{array}$ \\
\hline $\begin{array}{l}\text { Rail vehicle, } \\
\text { railwayman's error }\end{array}$ & Crash between rail vehicles & \multirow{6}{*}{$\begin{array}{l}\text { Derailing of a rail vehicle. } \\
\text { Damage to life and health of persons. } \\
\text { Loss of property. } \\
\text { Leakage of dangerous liquids and } \\
\text { environmental damage. } \\
\text { Interruption of transport. }\end{array}$} \\
\hline Obstacle on the track & Vehicle hitting an obstacle on the track & \\
\hline Road vehicle, pedestrian & $\begin{array}{l}\text { Collisions between rail vehicles and road vehicles, } \\
\text { including collisions between rail vehicles and } \\
\text { pedestrians at level crossing }\end{array}$ & \\
\hline Road vehicles & $\begin{array}{l}\text { Collisions between rail vehicles and road vehicles } \\
\text { outside the level crossing }\end{array}$ & \\
\hline Rail failure & Rail break, buckling of the track & \\
\hline Rail vehicle failure & Wheel rupture, rail vehicle axle failure & \\
\hline Man on the track & $\begin{array}{l}\text { Collision between a moving rail vehicle and } \\
\text { a person outside the level crossing }\end{array}$ & $\begin{array}{l}\text { Damage to life and health of persons. } \\
\text { Interruption of transport. }\end{array}$ \\
\hline $\begin{array}{l}\text { Rail vehicle, } \\
\text { railwayman's error }\end{array}$ & $\begin{array}{l}\text { Unsecured run of a rail vehicle, rail vehicle } \\
\text { runaway, train uncoupling }\end{array}$ & $\begin{array}{l}\text { Damage to life and health of persons. } \\
\text { Loss of property. }\end{array}$ \\
\hline $\begin{array}{l}\text { Rail vehicle, technical } \\
\text { failure }\end{array}$ & Rail vehicle fires & $\begin{array}{l}\text { Damage to life and health of persons. } \\
\text { Loss of property. } \\
\text { Threat to the environment. } \\
\text { Interruption of transport. }\end{array}$ \\
\hline $\begin{array}{l}\text { Technical failure } \\
\text { of a rail vehicle, } \\
\text { railwayman's error }\end{array}$ & $\begin{array}{l}\text { Release of dangerous goods during their } \\
\text { transport }\end{array}$ & $\begin{array}{l}\text { Damage to life and health of persons. } \\
\text { Threat to the environment. } \\
\text { Interruption of transport. }\end{array}$ \\
\hline
\end{tabular}

\section{Results}

\section{Mapping of Hazards on a Chosen Railway Stretch in the Moravian-Silesian Region}

In the territory of the Moravian-Silesian Region (see Fig. 2), the total track length is about $672 \mathrm{~km}$, of which about $392 \mathrm{~km}$ belong to the state and about $280 \mathrm{~km}$ to the regional railways.

For the mapping of hazards, a stretch of the railway route No. 270 (Česká Třebová - Přerov - Bohumín), namely the stretch between Ostrava Svinov and Jistebník was chosen. This railway route connects Prague with Northern Moravia, Silesia, Poland and Slovakia. The whole railway is electrified and double tracked. To a considerable extent, both passenger and goods transport take place here. The railway forms a boundary of the Poodři Protected Landscape Area in which a large number of protected and endangered species of fauna and flora occur.

From the above-mentioned characteristics, it is clear that any accident in this territory would have serious consequences influencing human life and health and causing damage to property, traffic flow interruption and environmental threats.

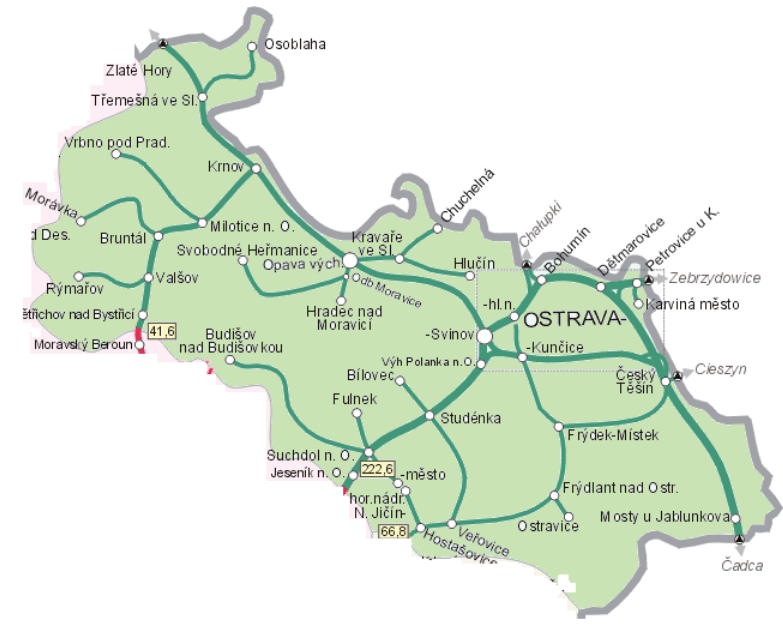

Fig. 2 Map of railway system of Moravian-Silesian Region (České dráhy, 2010)

\section{Hazard Map}

In the above-presented tables, threats that can manifest themselves, under certain conditions, almost in the whole railway track length are presented. In the following map (see Fig. 3), specific places on the track, at which an accident may occur in case of extraordinary event, are marked. 
Locations of at-grade and grade separated intersections (level crossings, bridges, underpasses) of railway tracks and roads and culverts are marked.

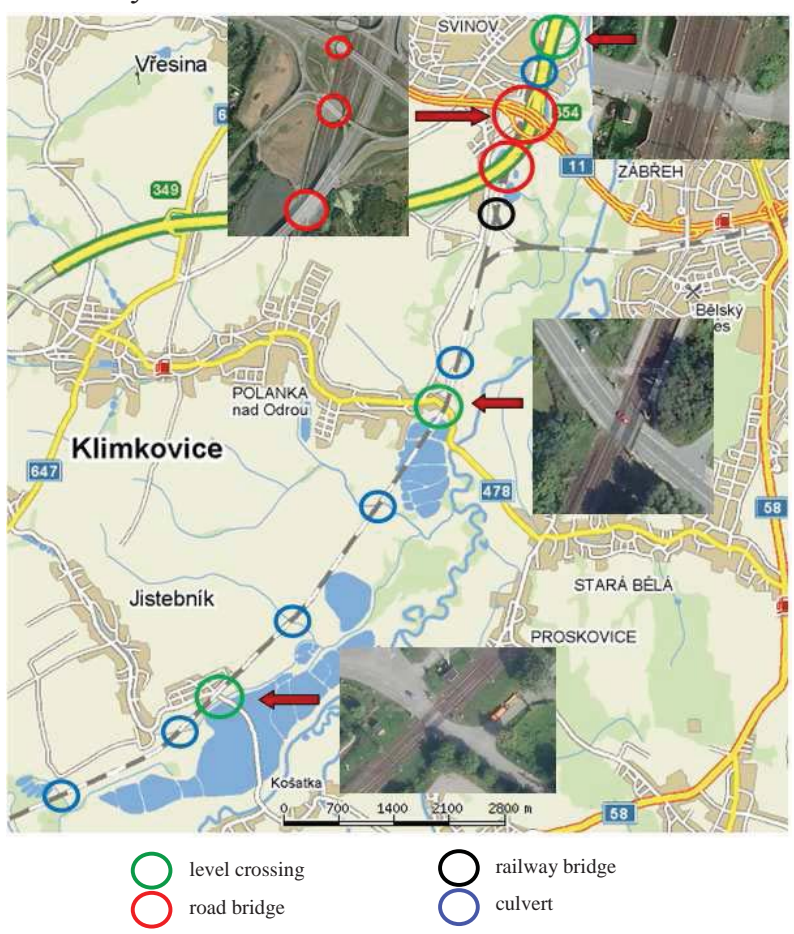

Fig. 3 Map of selected hazards on the railway route with marked critical points

On the Česká Třebová - Přerov - Bohumín railway route, on the Ostrava-Svinov - Jistebník stretch, altogether 14 danger points, at which an accident may occur, were identified. They are 3 level crossings, 4 road bridges, 6 culverts and 1 railway bridge.

Level crossings are places where a highway is intersected with a railway or another track lying on a separate bed, and have relevant traffic signs and markings (Zákon, 2000). At level crossings, collisions between trains and road vehicles (i.e. automobile, lorry, bus, etc.) occur most frequently. A common cause of these collisions is above all not respecting markings and signs and safety devices, placed in front of level crossings, by drivers of road vehicles who thus generally gamble with their lives, with the lives of fellow travellers and of other road users. One of the causes of collisions between a train and a car can also be an unfortunate coincidence, when a road vehicle remains standing due to mechanical failure at the level crossing/on the track.

Another way of intersecting railway tracks with roads and motorways is represented by road bridges leading over railway tracks. A typical example of what can happen is a rail accident that took place at Studénka on the $8^{\text {th }}$ August 2008, where a train crashed into the structure of a road bridge being repaired, which had fallen on the railway track several seconds ago (see Fig. 4).

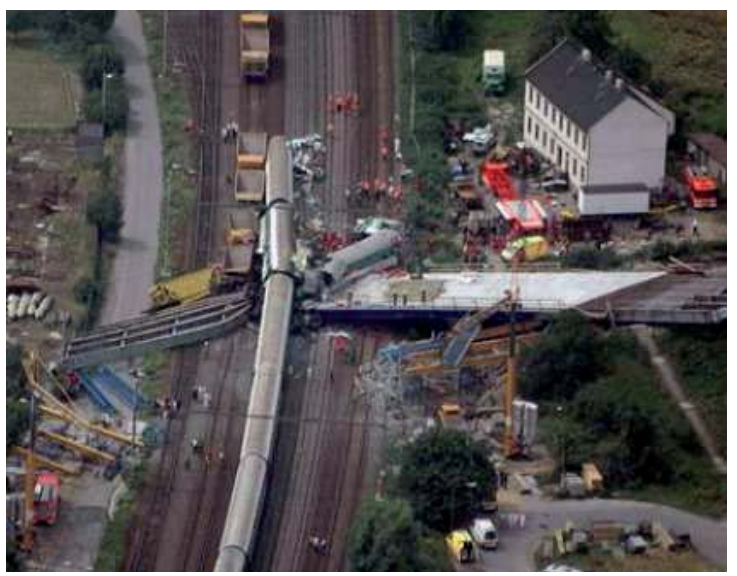

Fig. 4 Photo of Studénka train accident

Railway bridges are structures that are part of transport infrastructure. These structures serve as linking elements of the railway, e.g. over watercourses and roads. Thus they can compensate for difference in terrain height (i.e. viaducts). One of the causes of frequent traffic accidents is a bad estimation of the height of the bridge itself (especially in the case of lorries) and subsequent trapping the vehicle under the bridge structure. Railway bridges can also be damaged by floods harming the structures of the bridges.

Culverts are tunnel-type structures with a diameter of less than $2 \mathrm{~m}$, which are used to allow water to pass underneath embankments or to allow smaller animals to migrate underneath railway tracks, roads and other structures. These structures are becoming increasingly important above all in floodplains where, however, failures of culverts and subsequently damage to the railway track may occur owing to an increased discharge of water.

A significant factor is the presence of watercourses and hydraulic structures in the vicinity of the railway track. In the immediate vicinity of the chosen railway route (Česká Třebová - Přerov Bohumín, Ostrava-Svinov - Jistebník stretch), there are both several watercourses crossing the railway track (e.g. Porubka, Polančice, Bílovka, Mlýnka, and others) and hydraulic structures (e.g. pools Nádražní rybník, Polárkový rybník, Křivý rybník, Průtočný rybník, and others).

On the chosen railway stretch, a whole series of other accidents able to affect the course of travel may occur; they can involve the release of transported dangerous substances. To these accidents belong accidents caused by rail tank wagon failures (e.g. 
technical failures, mechanical failures of rail tank wagons), accidents due to human factor failures and accidents caused by natural influences (e.g. a fallen tree on the track as a result of unfavourable atmospheric conditions, sliding the land below the track or to the track, snow fallen on the track, etc.).

\section{Conclusion}

This contribution focuses, in the framework of the Moravian-Silesian Region, on the identification of danger points on the specific stretch of a railway route (Česká Třebová - Přerov - Bohumín, OstravaSvinov - Jistebník stretch) for the transport of dangerous substances. To the identified critical points on the selected railway stretch, level crossings, road and railway bridges and culverts belong. All these structures were plotted on a map.
Subsequently, causes of accidents that could occur at the designated danger points were determined. As a part of the mapping of hazards on any stretch of the railway route, it is also necessary to deal with hazards indirectly associated with the danger points (e.g. failures, errors, human factor, etc.).

The mapping of risks associated with the rail transport of dangerous substances will be further used for the preparation of the module "Railway" being just created for the prototype software system FLOREON $^{+}$.

\section{Acknowledgements}

This contribution was prepared as a part of the project of Student Grant Competition - project No. SP 2011/142 titled "Preparation of Module "Railway" for the FLOREON ${ }^{+}$System ".

\section{References}

JANOTA, Aleš, et al. (2008). Analýza a řizení rizik v dopravě: Pozemní komunikace a železnice. BEN - technická literatura, 2008. 528 s. ISBN 978-80-7300-214-5.

KRÖMER, Antonín, MUSIAL, Petr, FOLWARCZNY, Libor (2010). Mapování rizik. 1. vyd. Ostrava: Sdružení požárního a bezpečnostního inženýrství, 2010. 126 s. ISBN 978-80-7385-086-9.

ORAVEC, Milan (2009). Posudzovanie rizik. Ostrava: SPBI Ostrava, 2009. 106 s. ISBN 978-80-7385-043-2.

ŠIMÁK, Ladislav, et al. (2006). Terminologický slovník krízového riadenia. Žilina: Fakulta špeciálného inžinierstva Žilinskej univerzity v Žilině, 2006. 44 s. ISBN 80-88829-75-5.

ROUDNÝ, Radim (2008). Rozhodování a analýza rizik. In Sborník příspěvků z mezinárodní konference Ochrana obyvatel 2008. Ostrava: Vysoká škola báňská-Technická univerzita Ostrava, 2008. s. 347-354. ISBN 978-807385-034-0.

Ministerstvo dopravy. Ročenka dopravy České republiky 2009 (2010). Praha: Centrum dopravního výzkumu, v. v. i., 2010. 165 s. ISSN 1801-3090.

United States of America. Standard practice for system safety: MIL-STD-882D. 2000, s. 31.

Zákon č. 361/2000 Sb., o provozu na pozemních komunikacích a o změnách některých zákonů (zákon o silničním provozu) ve znění pozdějších předpisů.

České dráhy, a.s. Mapa tratís vyznačením hranic kraju․ [online]. 2010 [cit. 2011-10-06]. Available at WWW: $<$ http://www.cd.cz/vnitrostatni-cestovani/mapa-site/mapa-trati/-5958/>

Ministerstvo dopravy $\check{C} R$ [online]. 2011 [cit. 2011-10-01]. Available at WWW: <http://www.mdcr.cz/cs/default.htm>. 